\title{
USAHA MAKANAN RINGAN BERBAHAN DASAR SINGKONG
}

\author{
R. Bambang ${ }^{1}$, Aprianis ${ }^{2}$ \\ Universitas Sang Bumi Ruwa Jurai \\ ${ }^{1), 2)}$ Pascasarjana, Prodi Magister Manajeman \\ bsutrisno786@gmail.com, aprianisdl@gmail.com
}

\begin{abstract}
Abstrak
Makanan cepat saji banyak digemari dan menjadi tren bagi masyarakat Indonesia. Singkong merupakan sumber energi yang kaya akan karbohidrat. Kecenderungan mengonsumsi makanan modern menjadi tren bagi masyarakat Indonesia. Permasalahannya banyak masyarakat tidak mengetahui bahwa singkong sangat baik dijadikan sebagai makanan pokok pengganti beras Disamping singkong adalah makanan yang kaya serat dan rendah kalori, singkong juga bermanfaat bagi kesehatan oleh karennya tamanan singkong bisa diberdayakan secara lebih maksimal lagi. Metode yang digunakan dalam penelitian ini yaitu dengan menggunakan analisa swot dan survey pasar. Berdasarkan penelitian diperoleh kesimpulan bahwa usaha makanan ringan berbahan singkong dapat dilakuakan dengan : bekerjasama dengan petani singkong untuk produksi bahan baku singkong, pengembangan dilakukan dengan menambah lahan milik sendiri, mempekerjakan orang baru untuk bekerja (membuka lapanagan pekerjaan), menyiapkan distributor yang optimal
\end{abstract}

Kata Kunci : Makanan Ringan, Singkong

\section{Abstract}

Fast food is much popular and has become a trend for Indonesians. Cassava is a source of energy which is rich in carbohydrates. The tendency to consume modern food is a trend for Indonesian society. The problem is that many people do not see that cassava is very good as a staple food for rice. Besides being a diet rich in fiber and low in calories, cassava is also beneficial for health because cassava plantations can be maximally utilized. The method used in this research is by using SWOT analysis and market survey. Based on the research obtained from that light work-based business can be done by: working with farmers for the production of cassava raw materials, development is carried out by adding their own land, new people to work (opening work windows), preparing optimal distributors

Keywords: Snacks, Cassava

\section{PENDAHULUAN}

Singkong merupakan pohon tahunan tropika dan subtropika yang dapat ditanam sepanjang tahun,dan hamper disetiap wilayah diI ndonesia. Bagian yang dimakan dari tanaman singkong selain bagian umbi atau akarnya juga daunnya, biasanya dimanfaatkan untuk ragam masakan, terutama sayuran. Harga singkong yang relative murah juga dapat menjadi potensi dalam pengembangan kegiatan pengolahan menjadi produk yang banyak variasinya.Selainitu, latar belakang pengolahan singkong ini adalah untuk meningkatkan pendapatan dari sector pertanian (perkebunan). Singkong dapat dimasak dengan berbagai cara, dapat digunakan pada berbagai macam masakan.Namun sedikit kelemahannya, umbi singkong tidak tahan di simpan lama meskipun ditempatkan di lemari pendingin, untuk itu butuh pengolahan lebih lanjut agar lebih tahan lama.

Di lihat dari manfaatnya, umbi singkong merupakan sumber energi yang kaya karbohidrat namun sangat miskin akan protein. Sumber protein yang bagus justru terdapat pada daun singkong karena mengandung asam aminometionin.Umbi akar singkong banyak mengandung glukosa dan dapat dimakan mentah. Menurut pakar tanaman obat Prof.Hembing Wijayakusuma, efek farmalogis dari singkong adalah sebagai anti oksidan, anti kangker, 
antitumor, dan menambah nafsu makan. Umbi singkong juga memiliki kandungan kalori, protein, lemak, hidratarang, kalsium, fosfor, zatbesi,vitamin $\mathrm{B}$ dan $\mathrm{C}$, dan amilum.Daun singkong sendiri mengandung vitamin A,B1,dan C, kalsium, kalori, fosfor, protein, lemak, hidrat arang, dan zat besi. Sementara kulit batang, mengandung tannin, enzim peroksidase, glikosida, dan kalsium oksalat.

Kecenderungan mengonsumsi makanan modern menjadi tren bagi masyarakat Indonesia, Makanan-makanan cepat saji menjadi banyak di gemari, terutama oleh masyarakat muda. Kemudian pengolahan secara modern inilah yang menjadikan produk-produk makanan saat ini dapat bertahan di pasar makanan. Kenyataanya, pada rumah makan yang menggunakan konsep modern tidak pernah kita temukan dalam keadaan sepi. Kreatifitas dituntut dalam pengolahan makanan-makanan yang akan dijual, dengan diiringi modernisasi dibanyak hal, alangkah baiknya jika kita dapat mempertahankan makanan local dengan adanya sedikit penyesuaian kepada modernisasi.

Diversifikasi pangan adalah peningkatan keragaman bahan pangan yang saat ini sedang diinisiasikan oleh pemerintah Indonesia. Menurut menteri pertanian,sebenarnya keberagaman pangan sangat baik untuk kesehatan. Terdapat banyak pilihan makanan pokok selain nasi yang dapat menggantikan posisis nasi sebagai kebutuhan pangan tertingi saat ini diIndonesia. Indonesia saat ini berada dalam peringkat tertinggi,Negara yang mengonsumsi beras, mengalahkan Malaysia dan Thailand yang nota bene makanan pokoknya adalah nasi. Sehingga Menteri Pertanian menganjurkan agar rakyat Indonesia mengonsumsi makanan pokok secukupnya untuk memenuhi kebutuhan kabohidrat, dan menambah asupan sayur dan buahDiharapkan jenis usaha yang kami rencanakan ini dapat mendukung usaha pemerintah dalam menerapkan diversifikasi pangan bagi masyarakat Indonesia.

Kementerian Lingkungan Hidup dan Kehutanan ( Kemen LH ) menerapkan arahan Menteri Pendayagunaan Aparatur Negara untuk menyiapkan hidangan atau penganan yang menggunakan bahan dasar pangan lokal, dalam setiapacara seperti singkong tetapi, menu tradisional tersebut jarang disentuh oleh tamu undangan, terutama singkong rebusnya. Dengan kata lain menu singkong sepi peminatnya. (Menteri LH,2014) Banyak masyarakat tidak mengetahui bahwa singkong sangat baik dijadikan sebagai makanan pokok pengganti beras Disamping singkong adalah makanan yang kaya serat dan rendah kalori, singkong juga bermanfaat bagi kesehatan antara lain Membantu menurunkan berat badan., Menyembuhkan migraine, Meningkatkan pencernaan, Mengobati diare. dan penglihatan Banyak petani singkong yang belum maksimal memasarkan singkong hasil panennya (Kompasiana, 2013) Padahal Kebutuhan makan anakan sumber karbohidrat( makanan pokok alternatif).Selain hidangan nasi dan lauk, singkong dapat juga disajikan dengan lauk dan dapat menggantikan kebutuhan makanan berat. Selain itu, singkong dapat untuk memenuhi kebutuhan akan camilan juga dan dapat dipenuhi dengan komposisi singkong sebagai dessert.( pencuci mulut ). Produksi ubi kayu atau singkong Provinsi Lampung secara genetik mampu menghasilkan lebih dari 25 ton per hektare (ha). Untuk itu kita harus mengupayakan bagaimana tanaman singkong kita dapat diberdayakan secara maksimal disamping untuk memenuhi kebutuhan industri dll. umumnya makanan cemilan khususnnya

\section{METODE}

Beberapa metode yang digunakan dalam pelaksanaan sebagai berikut;

\section{Analisa SWOT}

\section{STRENGTHS}


a. Produk memiliki nilai Gizi tinggi

b. Bahan baku produk berpotensi untuk dihidangkan bersama seluruh jenis makanan, baik makanan ringan maupun berat, baik rasanya asin atau manis dan tawar.

c. Harga terjangkau bagi semua kalangan

d. Desain kedai yang unik dan menyediakan fasilitas bermain bagi keluarga.

\section{OPPORTUNITIES}

a. Gaya hidup masyarakat yang senang makan diluar rumah

b. Kaum sosialita cenderung mencari kuliner unik

c. Bahan bakumudahdidapatkarenabanyak diproduksidi Lampung

Harga bahan baku murah (hargabeli rendah) Lokasi kedai mudah

ditemukan

\section{WEAKNESSES}

a. Padaawalpendiriankedai, pekerjakedaimasihterbatas

b. DesainkedaiyangBahanbaku belumdapatdiproduksidi lahan sendiri

c. Hargaterjangkaubagisemua kalangan

d. Desainkedaiyangunikdan menyediakanfasilitasbermain bagi keluarga

\section{THREATS}

a. Terdapat pesaing makanan yang beraneka rasa walaupun berbahan dasar selain singkong

b. Tantangan dalam menemukan tenaga ahli di bidanga tata boga dan kuliner

c. Tantangan untuk menemukan arsitek yang dapat mendesain interior kedai

d. Baham baku belum dapat ditanam di lahan milik sendiri.

\section{Survey Pasar}

Apakah pasar menyukai ide Produk Aspeta ini dilakukan

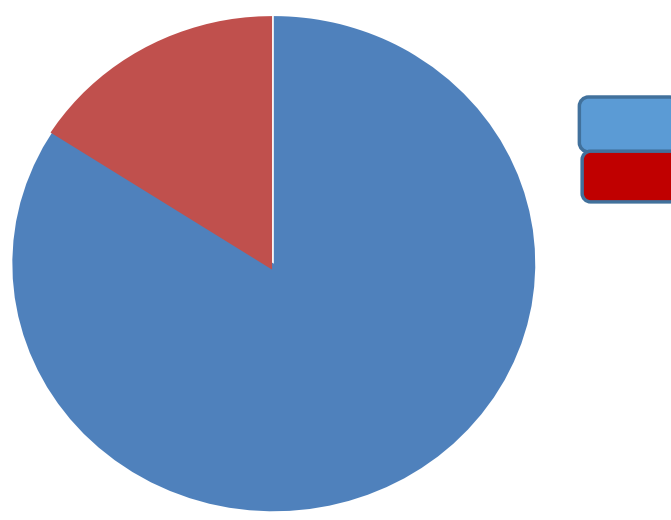

\section{SUKA $\quad 92,5 \%$}

TIDAK SUKA $\quad \mathbf{7 , 5} \%$ 


\section{Alasan menyukai Produk}

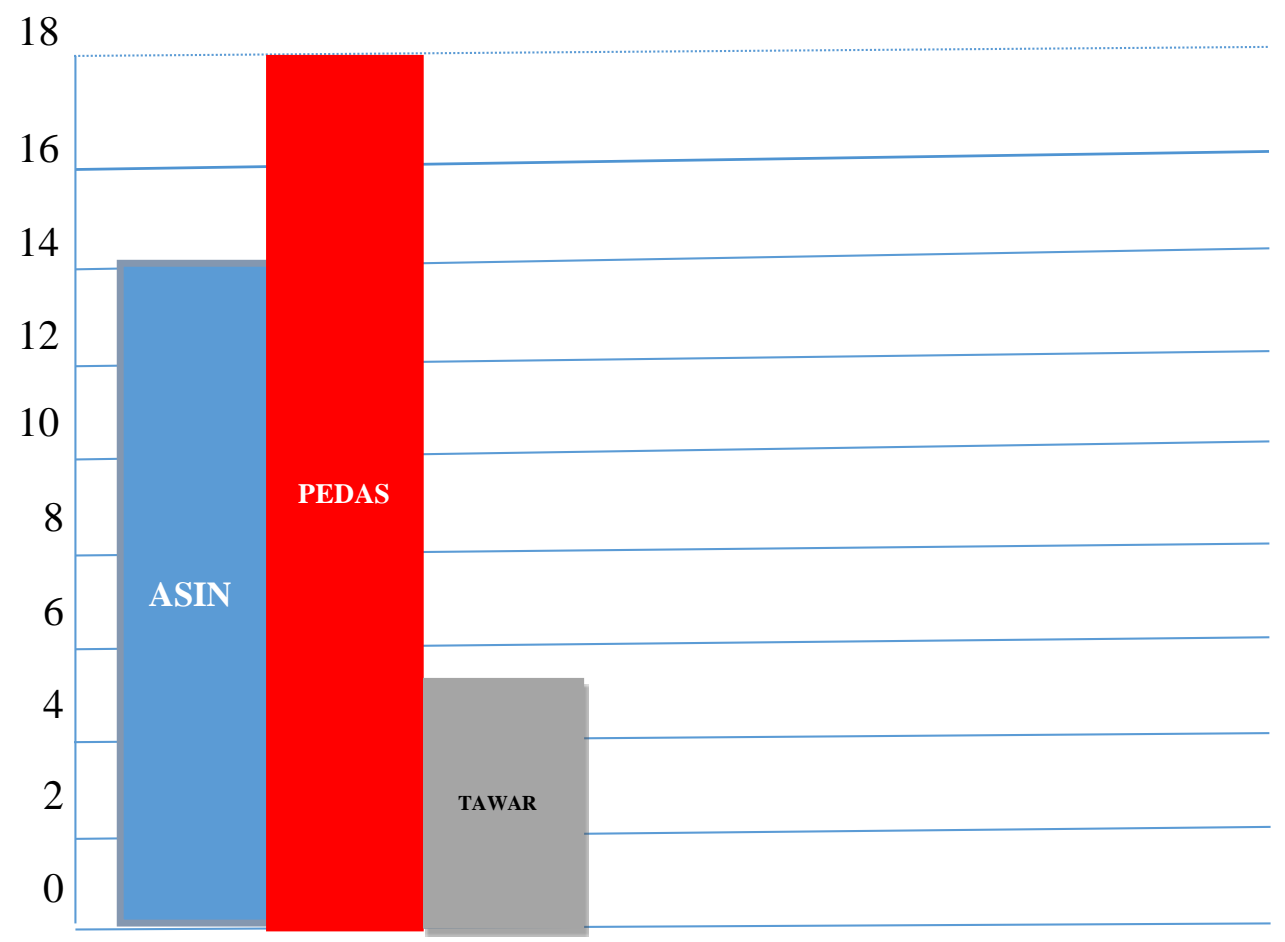

Berdasarkan hasil survey, responden yang menyukai ide Aspeta memiliki alasan:

1. Harga pembelian terjangkau sehingga semua kalangan dapat membeli produk ini,

2. Fasilitas(tempat, cara melayani pembeli) unik dan modern sehingga beberapa tertarik untuk dating dan menggunakan fasilitas yang ada dikedai,serta sajian beraneka rasa citara saying membuat singkong sederhanat erlihat semakin lezat.

3. Analisis Calon Pembeli

Kedai Aspeta dibuat dengan segmentasi seluruh lapisan masyarakat dari anak- anak (diatas5 tahun) hingga orang dewasa. Cocok sebagai kedai bagi keluarga.

4. Prakiraan Biaya yang masyarakat dapat terima Rp10.000-25.000,

5. Kebutuhan masyarakat yang terpenuhikebutuhan makan anak an sumber karbohidrat (makanan pokok alternatif).Selain hidangan nasi dan lauk, singkong dapat disajikan dengan lauk dan dapat menggantikan kebutuhan makanan berat. Selainitu, kebutuhan akan camilan juga dapat dipenuhi dengan komposisi singkong sebagai dessert.

6. Peluang Produk Aspeta yang dipilih

Ketertarikan pada sarana pra sarana kedai dan produk yangbercita rasa pemenuhan dessert dan makanan berat berbasis singkong

7. Lokasi Kedai Aspeta

Puat kota Bandar lampung, alasan: strategis, masyarakat Lampung cinta kuliner yang unik

8. Tren Masyarakat hari ini

- Tren untukmengunggahfoto di mediasocial

- Tren untukmenginformasikanaktivitaspribadidimediasosial

- Tren untukmenginformasikan"lokasisaat ini" di mediasocial 
9. Gaya Hidup

- Masyarakatcenderungmakan diluarrumah

- Masyarakatcenderungmencarihalpraktis/cepatsaji

- Masyarakatsemakinmemerhatikangizisetiapmakanan:polahidupsehat

\section{HASIL DAN PEMBAHASAN}

Hasil dan Solusi serta Tartget Luaran yang diperoleh sebagai berikut

1. Bekerjasama dengan petani singkong untuk produksi bahan baku singkong

2. Pengembangan dilakukan dengan menambah lahan milik sendiri.

3. Mempekerjakan orang baru untuk bekerja (membuka lapanagan pekerjaan)

4. Menyiapkan distributor yang optimal.

\section{BIAYA DAN JADWAL KEGIATAN}

\section{a. Biaya}

MODAL AWAL:

( di dapat dari meminjam ke Bank sebesar

$80 \%$ dan $20 \%$ biaya pribadi )

Biaya Pembelian

(rincian terlampir)

Biaya Penjualan

(rincian terlampir)

Keuntungan
Rp200.000.000,-

Rp157.170.000,-/tahun

Rp310.250.000,-/tahun

Rp 153. 080. 000,-/tahun

b. Jadwal Kegiatan Program

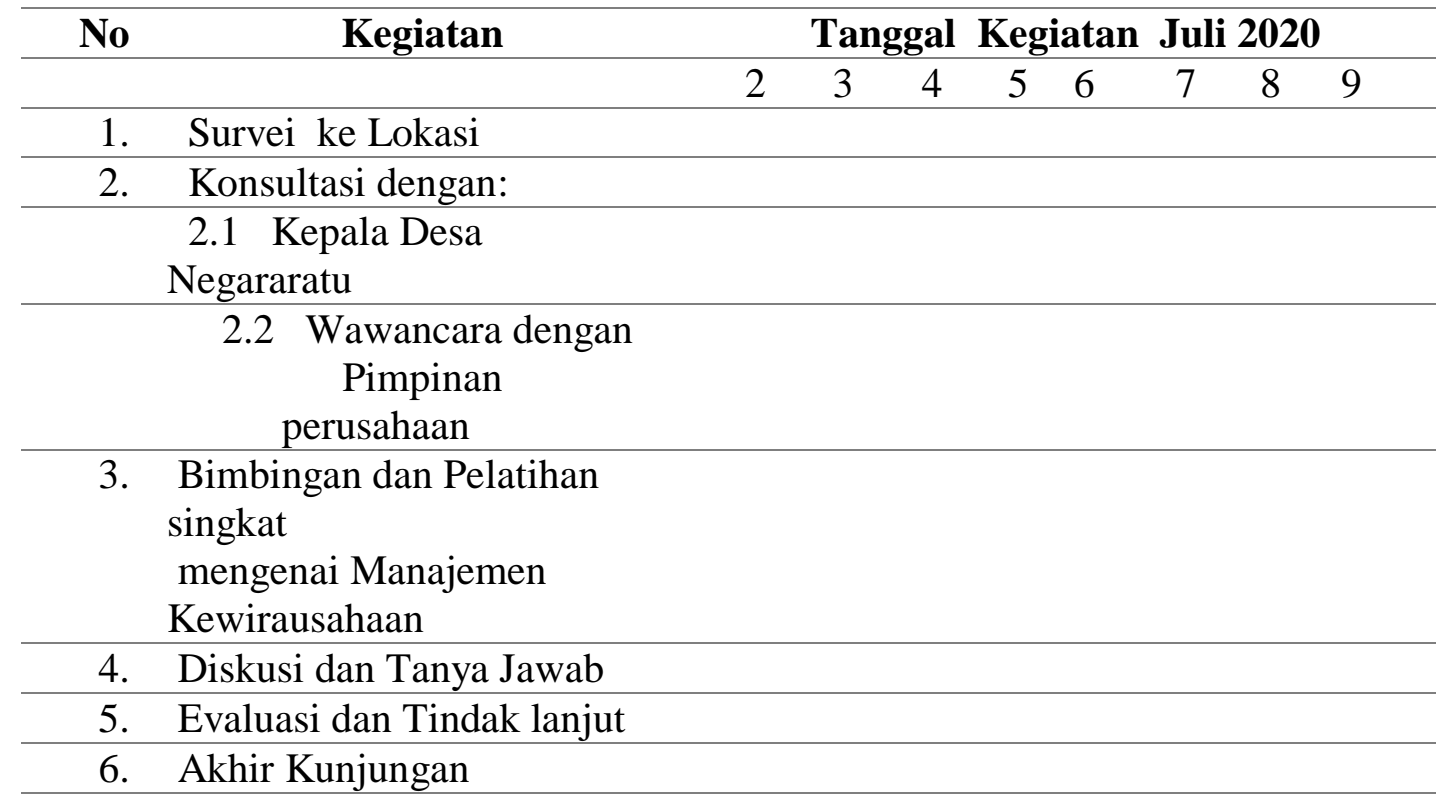

KESIMPULAN DAN SARAN

1. Bisnis makanan dari bahan baku singkong diprediksikan dapat memeroleh keuntungan 
Seminar Nasional Penelitian dan Pengabdian kepada Masyarakat

Universitas Sang Bumi Ruwa Jurai Tahun 2020

2. Masyarakat semakin termotivasi untuk mencari makanan lain selain nasi sebagai makanan pokok sumber karbohidrat

3. Aspetadapatmenjawabjulukan“Harga kaki lima, fasilitas bintang lima"melalui rancangan produksi produk dan desain kedai

\section{DAFTAR PUSTAKA}

Aristanto , 1996 Pemberdayaan Usaha Kecil, Science Journal No:25 Desember Universitas Merdeka Malang

Badan Pusat Statistik,2016 Produksi Ubi Kayu menurut Provinsi (ton) 1993-2015, http// www.bps.go.id

Lpsey , 1990 , Pengantar Mikroekonomi 1, jilid 1,Penerbit Erlannga, Jakarta.

Nicholson, 2000, Mikroekonomi Intermediate dan Aplikasinya, Edisi Kedelapan, Penerbit Erlangga

Prasasto, S. 2008. Aspek Produksi Keripik Singkong. http://WordPress.com. diakses pada hari selasa 11 Mei 2009.

Rahardjo, 1979 Hukum dan perubahan sosial suatu tinjauan teoritis secara pengalaman di Indonesia, penerbit Alumni Bandung.

Soekartawi, 2002, Prinsip-prinsip Dasar Manajemen Pemasaran Hasil Pertanian; Teori dan Aplikasinya, Penerbit Rajawali Pers.

Todaro, 2009, Pembangunan ekonomi, jilid 1, Penerbit : Erlangga Jakarta 